\title{
Pemasangan Alat Penyulingan Serai Wangi untuk Petani di Desa Siabu, Salo, Kampar
}

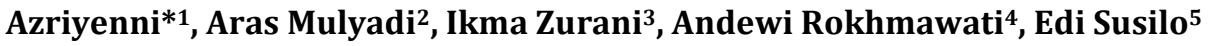 \\ 1,5Jurusan Teknik Elektro, Fakultas Teknik, Universitas Riau \\ 2Jurusan Ilmu Kelautan, Fakultas Perikanan \& Kelautan, Universitas Riau \\ 3Jurusan Ilmu Komunikasi, FISIP, Universitas Riau \\ 4Jurusan Manajemen, Fakultas Ekonomi, Universitas Riau \\ * e-mail: azriyenni@eng.unri.ac.id ${ }^{1}$
}

\begin{abstract}
Lemongrass is an alternative to several raw materials to produce citronella oils. Citronella oils are useful for a mixture of cosmetics, aromatherapy, medicines, supplements, and others. This community service activity aims to implement innovative necessary oil distillation devices for appropriate technology products to increase the production of citronella oils for farmers in Siabu Village, Salo District, Kampar, Riau Province. The community can understand and improve the quality of the yield so that the quality of oil becomes better and benefits the community. The method of implementation consists of field surveys, situation analysis, design of the device, installation of devices, and monitoring of data collection, and analysis according to the theories cited to obtain information. In the distillation of citronella oil, there are three ways, that's are; distillation using a boiling system, distillation using water and steam systems, distillation using the direct steam system. The refining citronella oil have a capacity of $130 \mathrm{~kg}$ per kettle that can produce 1.3 liters of citronella oil. They were greatly helped by using the distillery properly according to the SOP which was demonstrated directly, and according to the book that had been designed. Also, it was given to the lemongrass farmers in Siabu Village, Salo, Kampar, Riau, Indonesia.
\end{abstract}

Keywords: citronella oil, distillation, lemongrass

\begin{abstract}
Abstrak
Serai wangi adalah alternatif dari sekian bahan baku untuk menghasilkan minyak atsiri. Minyak atsiri dapat berfungsi sebagai campuran kosmetik, aromaterapi, obat-obatan, suplemen, dan lainnya. Kegiatan pengabdian masyarakat ini bertujuan untuk menerapkan inovasi alat penyulingan minyak atsiri dalam bentuk produk teknologi tepat guna untuk meningkatkan hasil produksi minyak atsiri bagi petani di Desa Siabu, Kecamatan Salo, Kabupaten Kampar, Provinsi Riau. Masyarakat juga dapat mengetahui dan memahami, serta meningkatkan mutu rendemen agar kualitas minyak menjadi lebih baik sekaligus bemanfaat bagi masyarakat. Metode pelaksanaan terdiri dari survei lapangan, analisis situasi, rancangan alat, pemasangan alat, dan pemantauan alat pengumpulan data, dan analisis sesuai dengan teori-teori yang dikutip untuk memperoleh informasi. Dalam penyulingan minyak serai wangi terdiri dari tiga cara yakni; penyulingan menggunakan sistem rebusan, penyulingan menggunakan air dan uap, penyulingan menggunakan uap langsung. Hasil penyulingan serai wangi menjadi minyak atsiri dengan kapasitas $130 \mathrm{~kg}$ per-ketel dapat menghasilkan minyak atsiri 1,3 liter. Mereka sangat terbantu dengan cara menggunakan alat penyulingan secara baik sesuai SOP yang didemokan secara langsung, dan sesuai dengan buku yang telah dirancang dalam buku TTG juga diberikan kepada kelompok tani serai wangi di Desa Siabu, Salo, Kampar, Riau, Indonesia.
\end{abstract}

Kata kunci: minyak atsiri, penyulingan, serai wangi

\section{PENDAHULUAN}

Serai wangi merupakan salah satu tumbuhan yang digunakan sebagai campuran makanan dan obat-obatan. Minyak atsiri dari serai wangi dapat menghasilkan bahan ekstraksi. Salah satu cara yang tidak membutuhkan suhu yang tinggi dan tidak akan mudah rusak (Farah Nabila et al., 2019). Maka, suatu ketel dari bahan yang efektif dan memiliki inovasi yang menghasilkan minyak atsiri yang dengan produksi rendemen yang bagus. Proses alat penyulingan secara efisien dapat diperoleh minyak atsiri memiliki kualitas yang baik, dan kuantitas yang banyak (Irawan, 2010). Serai wangi adalah salah satu tanaman yang mudah dibudidayakan dan tidak memerlukan 
perlakuan khusus. Maraknya petani serai wangi bagi masyarakat dikalangan perkebunan sangat menarik daya minat untuk mengembangkan peluang perkebunan serai wangi ini (A. Anwar, Nugraha, A. Nasution, 2016). Serai wangi sangat mudah tumbuh dan sangat sesuai ditanam pada iklim apapun dengan berbagai kondisi tanah. Setelah proses penanaman, petani dapat memanen serai wangi untuk pertama kali setelah berumur enam bulan. Dijangka untuk panen serai wangi dalam satu tahun sebanyak 4 kali (Arifin et al., 2017).

Masa panen yang singkat ini, membuat tanaman penghasil minyak atsiri ini mulai digemari oleh masyarakat. dalam rentang waktu lima tahun, petani tidak perlu lagi menanam bibit baru. Bahkan, jika tanaman ini dirawat dan dipupuk dengan baik, masa produktif serai wangi dapat mencapai umur sepuluh tahun. Hasil panen serai wangi ini sangat berdampak pada para kelompok tani, karena harga jual minyak serai wangi dapat meningkatkan perekonomian ekonomi masyarakat (Feriyanto et al., 2013).

Nurul Widji Trianna, dkk telah melakukan penelitian terkait kondensor, kondensor menghasilkan cairan, dengan menambahkan air untuk Nilam. Nilam adalah limbah pirolisis yang memiliki secara reaksi kimia. Hasil penelitian pirolisis nilam Limbah N2 terdiri dari atmosfer pada suhu dari $250^{\circ} \mathrm{C}$ hingga $500^{\circ} \mathrm{C}$ (Trianna et al., 2014). Ayu Chandra K. F \& Fikka Kartika W telah penelitian menghasilkan limbah kulit jeruk sekitar 500.000 ton per-tahun. Pemanfaatan limbah kulit jeruk dapat dilakukan dengan mengekstraksi menjadi minyak atsiri. Metode ini dijalankan dengan cara kombinas pemanasan microwave, hidro-difusi dan gravitasi bumi pada tekanan atmosferik, tanpa penambahan pelarut organik ataupun air. Penggunaan microwave tidak memberikan perubahan pada struktur fisik minyak (W, 2017).

Muhammad Luthfi, dkk telah melakukan penelitian tentang metode ekstraksi minyak atsiri tidak diperlukan pada suhu tinggi, dan minyak tidak menjadi rusak. Perancangan alat destilator menggunakan proses observasi di lapangan, secara teori, artikel yang terkait pembuatan boiler. Boiler berfungsi sebagai tempat untuk memanaskan air sebagai media bahan baku tumbuhan serai. Desain gambar menggunakan software, dan pengujian dalam penggunaan alat boiler dan ketel. Rancangan boiler dan tangki penguapan adalah proses penguapan dari boiler menuju ketel dengan proses secara efisien, sehingga menghasilkan minyak atsiri dengan kualitas dan kuantitas lebih baik (Luthfi, 2018).

Oleh karena itu, pada pengabdian ini akan membantu petani serai wangi untuk alat penyulingan minyak atsiri dengan kapasitas $130 \mathrm{~kg}$ per ketel, dan dapat menghasilkan minyak atsiri 1,3liter untuk kelompok tani di Desa Siabu, Kecamatan Salo, Kabupaten Kampar, Riau.

\section{METODE}

Sistem penyulingan terdiri dari tiga faktor, diantaranya; besar tekanan uap digunakannya, unsur molekul dalam minyak, dan kecepatan menghasilkan minyak atsiri (Azriyenni, Aras Mulyadi, Andewi Rokhmawati, Edi Susilo, 2020). Pada sistem penyulingan air dengan cara ini dipergunakan untuk menghasilkan minyak atsiri memiliki daya ketahanan terhadap panas dari bahan kayu dan keras. Kualitas minyak atsiri diperoleh lebih baik, manakala suhu tidak cukup tinggi. Namun, tidak semua jenis bahan baku dapat dipergunakan dengan metode ini, seperti; bahan berisikan kandungan sabun, dan bahan yang mudah hangus. Karena, dengan adanya air akan menyebabkan sering terjadi efek hidrolisis, dan durasi penyulingan menghabiskan waktu yang Panjang (Arifin et al., 2017). Penyulingan dengan air bisa dikatakan metode yang paling mudah dilakukan. Bahan bisa mengapung diatas air atau terbenam menjadi sempurna, bergantung dari segi berat dan jumlah bahan baku dalam ketel. Sistem ini terdiri dari beberapa kelebihan, yakni; proses yang sederhana dapat menyuling minyak dari material dalam bentuk bubuk dari akar, kulit kayu, dan tumbuhan yang mudah membentuk jika kena panas (Farah Nabila et al., 2019).

Sistem penyulingan dengan uap ini menggunakan dan diperlukan air, uap panas dengan tekanan yang lebih besar dari satu atmosfer dialirkan melalui pipa uap. Metode yang digunakan 
untuk membuat minyak atsiri dari biji, akar, kayu yang mengandung komponen minyak yang bertitik didih tinggi. Kualitas minyak yang baik telah dihasilkan, tekanan dan suhu dapat diatur, durasi penyulingan lebih pendek (Guruakuntansi, 2020). Peralatan yang digunakan mahal dan menggunakan jasa tenaga ahli. Cara penyulingan ini memakai tekanan uap yang tinggi. Tekanan uap air yang diperoleh lebih tinggi daripada tekanan udara. Uap yang dipakai adalah uap jenuh atau uap yang terlalu panas dengan tekanan lebih dari satu atmosfer. Air sebagai sumber uap panas terdapat dalam boiler yang terpisah dari ketel. Metode penyulingan uap lebih cepat dalam hasilkan minyak atsiri dengan normal.

Metode penyulingan uap sangat sesuai dilakukan untuk bahan tumbuhan antara lain; kayu, kulit batang, bijian. Pada awalnya Metode penyulingan ini dipergunakan tekanan uap yang rendah, kemudian secara bertahap tekanan ditingkatkan. Proses penyulingan tekanan menjadi tinggi, maka unsur-unsur kimia dalam minyak akan mengalami de-komposisi. Jika bahan baku diperkirakan telah habis, maka tekanan uap perlu ditingkatkan menjadi tinggi untuk menyuling unsur kimia pada titik didih yang lebih tinggi (W. Bota, M. Martosupono, dan S. Ferdy Rondonuwu, K. Kunci, 2015).

Sistem penyulingan ini menggunakan peralatan seperti dandang. Minyak yang dihasilkan pada titik didih lebih yang rendah dari air yang dapat tersuling, mengakibatkan hasil penyulingan ini menjadi tidak sempurna, karena masih banyak minyak yang tertinggal dalam ampasnya (Jayanudin \& Rudi, 2011). Metode ini dilakukan dengan menggunakan bahan yang diletakkan pada piringan besi berlubang seperti; ayakan yang terletak beberapa sentimeter diatas permukaan air. Demikian penyulingan seperti ini disebut juga penyulingan tidak langsung. Cara penyulingan ini menggunakan uap bertekanan rendah, peletakan keduanya dalam satu ketel. Air yang dimasukkan dalam ketel diisi sampai sepertiga bagian. Bahan baku akan dimasukkan dalam ketel dilakukan secara padat dan ditutup dengan rapat. Saat direbus dan air mendidih, uap yang terbentuk melalui saringan pada lubang kecil dan melewati celah boiler (Feriyanto et al., 2013).

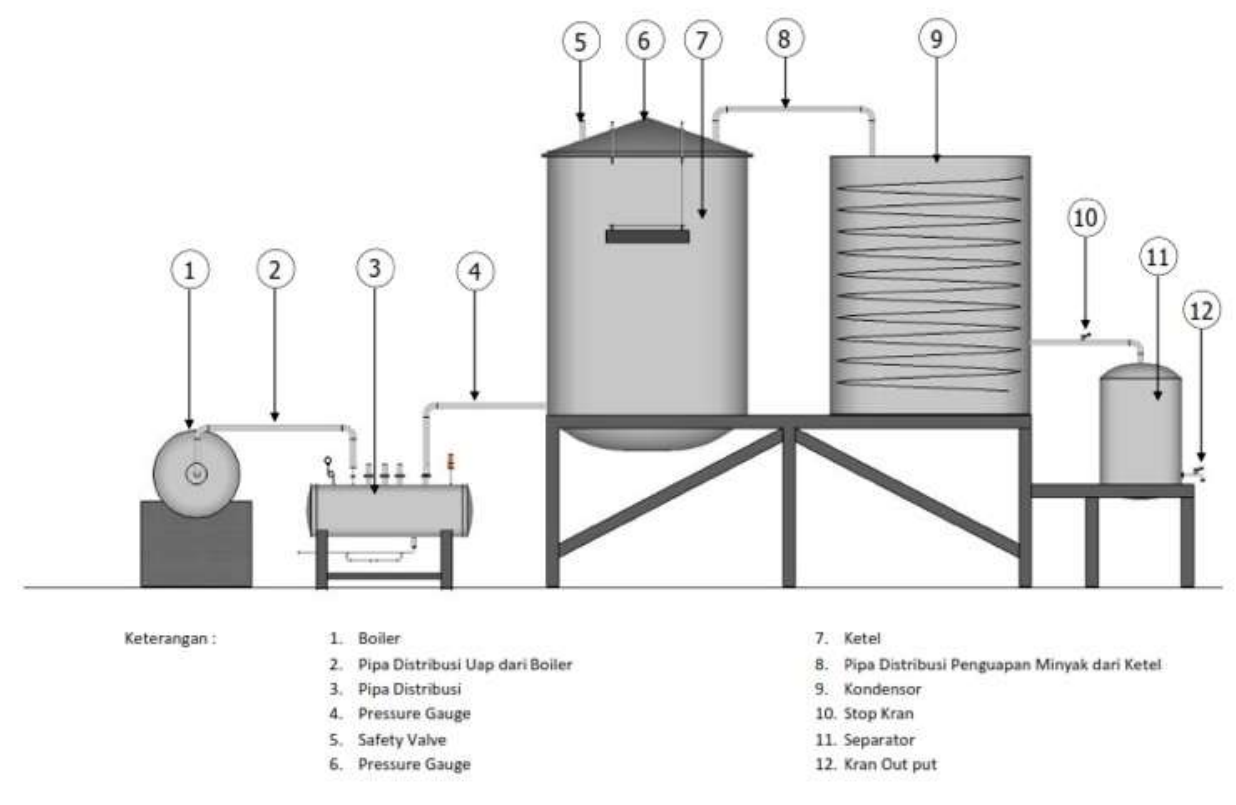

Gambar 1. Desain alat penyulingan untuk Desa Siabu, Salo, Kampar 
Gambar 1 adalah skema sistem penyulingan dengan cara sistem uap, dengan membuka katup kran untuk pengisian air ke dalam boiler. Pengisian air kedalam boiler, dan menyalakaan api pemanas pada boiler dengan nyala api yang cukup besar. Bahan baku tumbuhan serai wangi dilayukan, dan masukan bahan baku serai wangi secara bertahap hingga padat. Proses penyulingan berlangsung 3 sampai 4 jam, dengan memperhatikan tekanan didalam ketel sesuaikan dengan tekanan dalam boiler. Untuk melihat tekanan pada boiler dapat dilihat pada pressure gauge. Katup antara kondensor dengan ketel harus selalu perhatikan sirkulasi pendingin dibiarkan mengalir. Hasil dari alat penyulingan akan ditampung pada separator. Separator berfungsi untuk menampung hasil penyulingan dan pemisahan air dan minyak. Selama boiler bekerja kondensor juga akan tetap bekerja. Untuk mengetahui akhir proses penyulingan ini, dapat memperhatikan pada katup kran output separator. Apabila air tidak mengalir maka proses penyulingan dianggap selesai (Azriyenni, 2020).

\section{HASIL DAN PEMBAHASAN}

Minyak atsiri diperoleh dari bahan baku bersama uap panas dilalui oleh pipa menuju ketel dan kondensator. Uap air dan minyak menjadi mengembun dan ditampung dalam ketel pemisah. Pemisahan dilakukan didasarkan berat jenis, tumbuhan yang akan disuling berkaitan dengan uap dan tidak dengan air panas. Sistem penyulingan kombinasi air dan uap lebih efisien dari metode penyulingan air saja, karena jumlah bahan bakar yang dihabiskan sedikit, durasi penyulingan relatif singkat, serta hasilkan rendemen lebih besar.

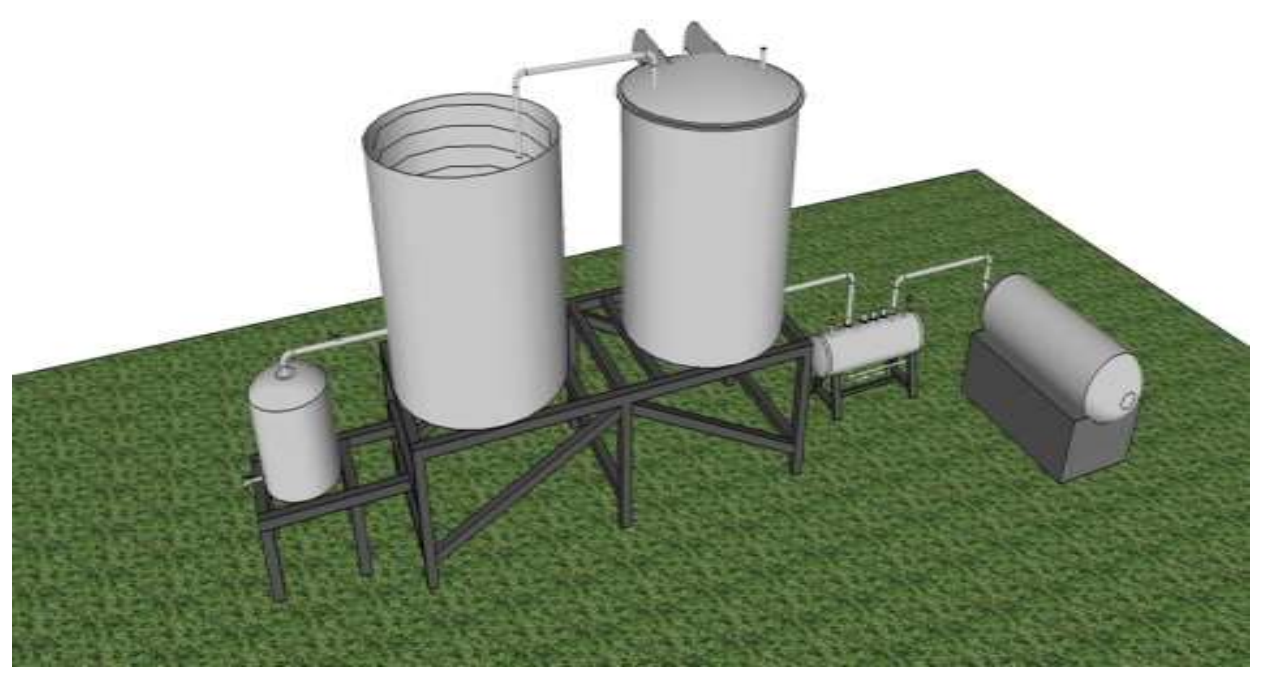

Gambar 2. Model alat penyulingan sistem uap di Desa Siabu, Salo

Gambar 2 adalah gambar model alat penyulingan yang dipasang di Desa Siabu, Kecamatan Salo, Kampar. Model sistem penyulingan ini terdiri dari boiler yang dihubungkan dengan ketel penyulingan, dihubungkan juga dengan pipa diameter dua inchi. Air digunakan untuk uap panas pada boiler dipisah dengan tangki penyulingan. Pada dasarnya boiler menggunakan kayu bakar dalam jarak tertentu. Bagian atas ketel penyulingan dan pipa spiral pada kondensor disambungkan ke pipa.

Sebelum melakukan pemasangan alat penyulingan serai wangi, perlu dilakukan informasi data yang terkait dengan dengan sistem penyulingan yang aka dirancang. Semakin lama proses sistem penyulingan, maka makin ada proses panas atau difusi terhadap bahan baku menjadi 
meningkat. Dengan kata lain, proses penyulingan akan makin cepat, dan rendemen minyak yang dihasilkan menjadi lebih baik. Proses penyulingan bahan baku yang lama, maka menghasilkan uap air yang banyak dengan minyak yang terkandung didalamnya. Tetapi, jika proses penyulingan lebih lama, maka rendemen minyak yang dihasilkan menjadi menurun. Jika suhu dan tekanan meningkat, maka rendemen minyak menjadi menurun. Proses polimersasi dapat menghasilkan polimer dengan berat molekul lebih tinggi.

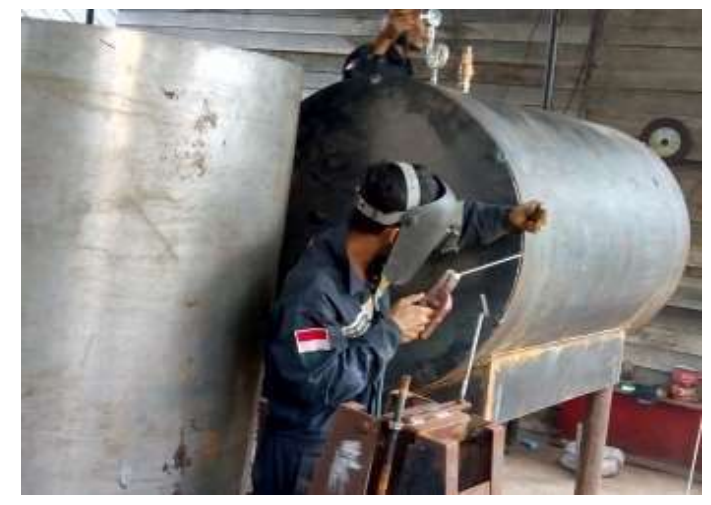

Gambar 3. Proses pengerjaan Boiler

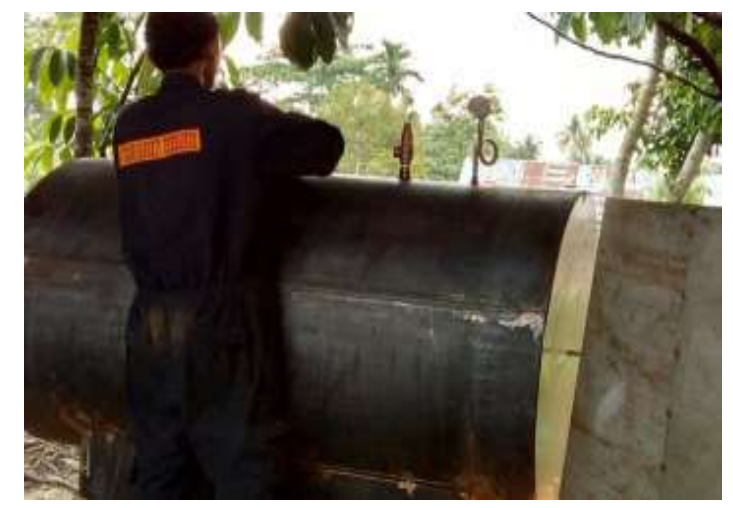

Gambar 4. Proses Pengerjaan Reaktor

Gambar 3 sampai 4 adalah alat penyulingan serai wangi yang dipasang di Kawasan perkebunan di Desa Siabu, Salo, Kampar. Alat penyulingan ini menggunakan cara sistem uap langsung. Cara penyulingan uap merupakan cara yang lebih cepat untuk meng- hasilkan minyak atsiri untuk tumbuhan serai wangi. Saat pemasangan alat penyulingan pondasi yang telah ada, boiler dipasang lebih rendah dari ketel penyulingan, manakala bagian atas boiler posisi rata dengan bagian dasar ketel penyulingan. Bagian atas boiler dengan bagian bawah ketel penyulingan, dihubungkan dengan pipa. Air sebagai sumber uap panas terdapat pada boiler yang terpisah dari ketel penyulingan. Pada boiler de- ngan tempat kayu bakar atau bahan bakar penyulingan berjarak dengan ukuran tertentu, jarak ideal yang diperoleh dari pengalaman para pelaku penyulingan.

Gambar 5 adalah sebuah ketel yang digunakan untuk pengukusan tumbuhan serai wangi yang dapat dimuati maksimum $130 \mathrm{Kg}$ dan dapat menghasilkan minyak atsiri 1,3liter yang dipasang di Desa Siabu, Kecamatan Salo, Kabupaten Kampar, Riau. Gambar 4 adalah suatu kondensor yang dipergunakan pada alat destilasi di Desa Siabu. Kondensor yang perlu diperhatikan adalah sirkulasi pendingin agar dapat mengalir. Hasil dari alat penyulingan akan ditampung pada separator. Gambar 5 adalah tungku pengukusan bahan baku serai wangi, digunakan kayu bakar untuk proses perebusan tumbuhan serai wangi.

Gambar 6 adalah kegiatan tim pengabdian dan mahasiswa KUKERTA Terinterigasi Abdimas Universitas Riau 2020 telah melakukan sosialisasi teknik penyulingan tumbuhan serai wangi menjadi minyak atsiri kepada petani di Desa Siabu, Kampar. Sosialisasi ini merupakan memberi informasi, dan penjelasan mengenai teknik penyulingan minyak atsiri kepada petani. Pada kegiatan kali ini tim Kukerta menjelaskan teknik penyulingan minyak atsiri dengan sistem uap. Kegiatan sosialisasi ini pula sangat bermanfaat bagi para petani. Mereka sangat terbantu dengan cara menggunakan alat penyulingan secara baik sesuai SOP yang didemokan secara langsung, dan sesuai dengan buku yang telah dirancang dalam buku TTG juga diberikan kepada kelompok tani serai wangi di Desa Siabu, Salo, Kampar. 


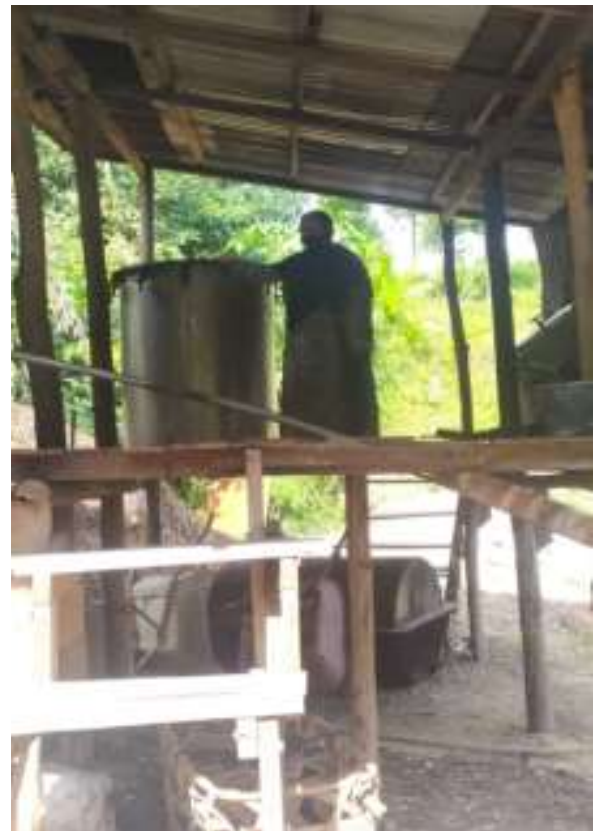

Gambar 5. Ketel penyulingan serai wangi di Desa Siabu, Salo

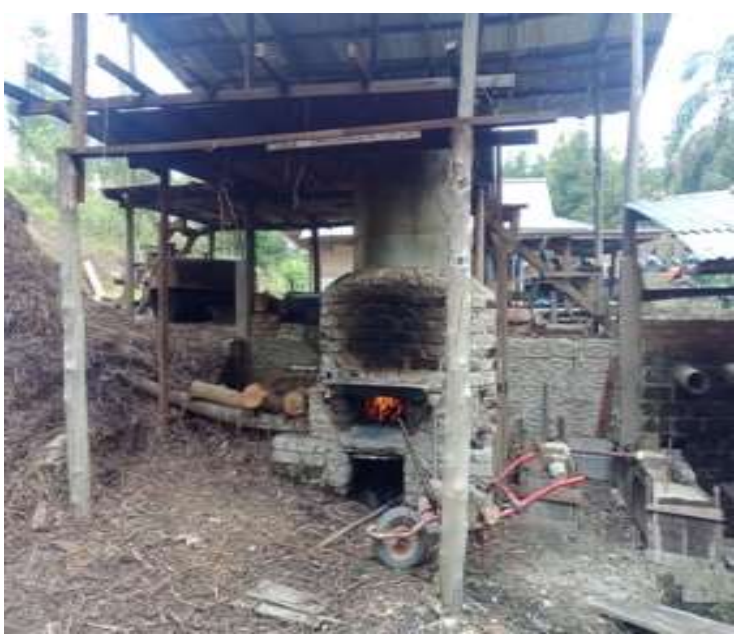

Gambar 7. Tungku pembakaran

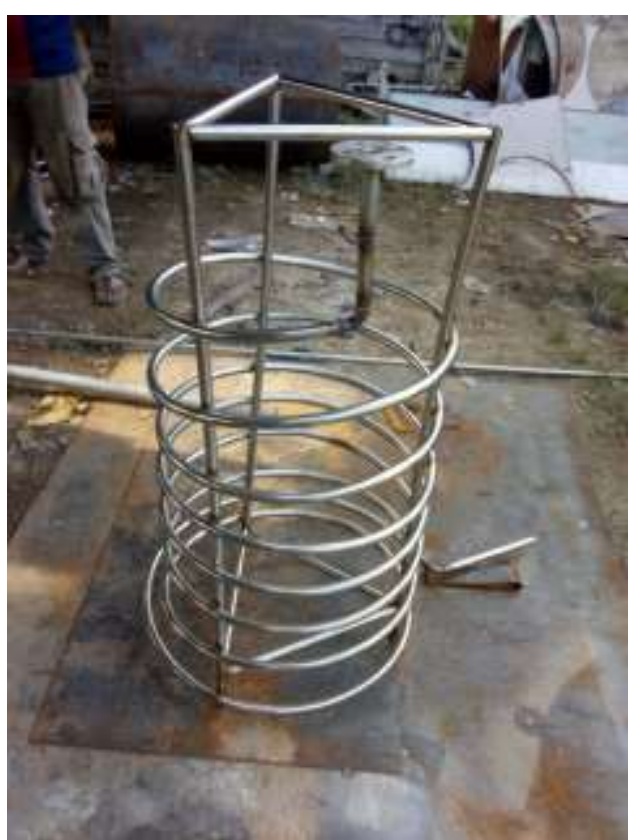

Gambar 6. Kondensor alat penyulingan

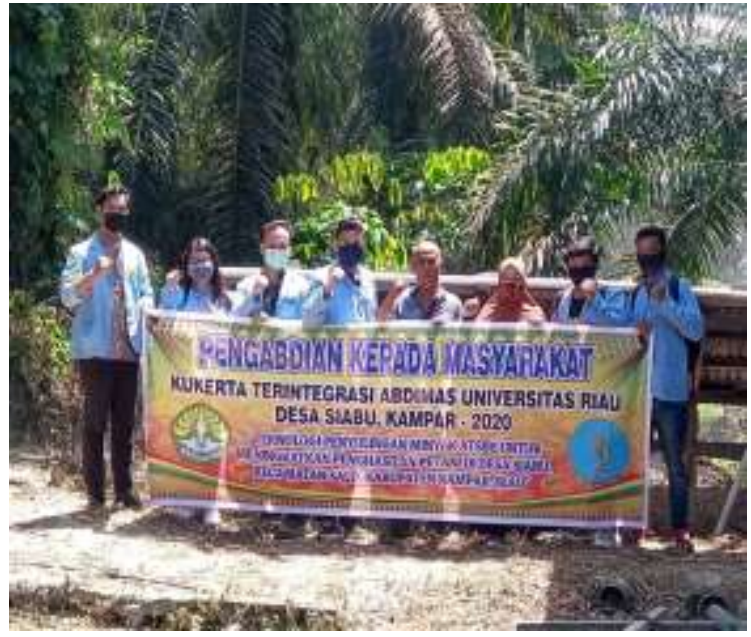

Gambar 8. Tim Pengabdian dan mahasiswa KUKERTA Terintegrasi Abdimas Universitas Riau di Desa Siabu, Kampar 2020

\section{KESIMPULAN}

Serai wangi sebagai bahan baku untuk menghasilkan minyak atsir berfungsi sebagai untuk produk kesehatan, kosmetik, dan lainnya. Perawatan tumbuhan serai wangi perlu dilakukan untuk meningkatkan hasil bahan baku, dengan cara memecah rumpun yang berukuran besar namun tidak beruas. Untuk pemasangan alat penyulingan ini perlu diperhatikan pondasi peletakan alat penyulingan, keadaan tanah yang kurang kering disebabkan hujan mempengaruhi proses pengeringan pondasi. Tata letak tungku pembakaran juga perlu diperhatikan untuk ketel perebusan yang memiliki muatan yang cukup berat, karena berisi bahan baku tumbuhan serai wangi. Kepada petani serai wangi di Desa Siabu, Kecamatan Salo, Kabupaten Kampar dihibahkan satu unit alat penyulingan minyak serai wangi dengan kapasitas $130 \mathrm{Kg}$ sekaligus 
pemasangannya. Dengan adanya alat penyulingan, mereka dapat menyuling secara baik sesuai SOP yang didemokan secara langsung, dan sesuai dengan buku yang telah dirancang dalam buku TTG juga diberikan kepada kelompok tani serai wangi di Desa Siabu, Salo, Kampar.

\section{UCAPAN TERIMA KASIH}

Penulis haturkan ucapan terima kasih kepada Lembaga Penelitian dan Pengabdian Masyarakat (LPPM) Universitas Riau telah mendukung Kegiatan ini melalui Hibah DIPA-UNRI 2020 terhadap skema pengabdian Kepada Masyarakat ini.

\section{DAFTAR PUSTAKA}

A. Anwar, Nugraha, A. Nasution, and R. A. (2016). Teknologi Penyulingan Minyak Serai Wangi Skala Kecil dan Menengah Di Jawa Barat.

Arifin, Z., Suzery, M., \& Cahyono, B. (2017). Kandungan Minyak Atsiri Daun Hyptis Pectinata Poit dari Jawa Barat. Seminar Nasional II USM 2017, 1, 541-546.

Azriyenni, Aras Mulyadi, Andewi Rokhmawati, Edi Susilo, I. Z. (2020). Cara Menyuling Serai Wangi Menjadi Minyak Atsiri.

Azriyenni, N. (2020). Alat Destilasi Minyak Atsiri Dengan Pemurnian Tiga Separator Menggunakan Sistem Uap (Patent No. P00202005116).

Farah Nabila, W., Nurmalina, R., Sulaswatty, A., Rusli, M. S., Abimanyu, H., \& Silvester Tursiloadi. (2019). Minyak Serai Wangi: Potensi Besar Yang Perlu Perhatian. In Quo Vadis Minyak Serai Wangi dan Produk Turunannya (Vol. 9, Issue 2). https://doi.org/10.29244/fagb.9.2.143-159

Feriyanto, Y. E., Sipahutar, P. J., Mahfud, \& Prihatini, P. (2013). Menggunakan Metode Distilasi Uap dan Air dengan Pemanasan Microwave. Jurnal Teknik POMITS, 2(1), 93-97.

Guruakuntansi. (2020). Destilasi Uap Air. https://guruakuntansi.co.id/destilasi-uap-air/

Irawan, B. (2010). Magister Teknik Kimia.

Jayanudin, \& Rudi, H. (2011). Proses Penyulingan Minyak Atsiri Dengan Metode Uap Berbahan Baku Daun Nilam. Jurnal Sains Dan Teknologi, 7(1), 67-75.

Luthfi, M. (2018). Atsiri Pada Mesin Destilator Dengan Metode Uap Berbahan Baku Daun Serai ( Cymbopogon Nardus ). 1(1), 9-20.

Trianna, N. W., Wahyudi, B., \& Mulyadi, E. (2014). Pembentukan Asap Cair Dari Ampas Nilam Dengan Proses Pirolisis. Teknik Kimia, 9(1), 15-21.

W. Bota, M. Martosupono, dan S. Ferdy Rondonuwu, K. Kunci, and M. S. W. (2015). Potensi Senyawa Minyak Sereh Wangi (Citronella Oil) dari Tumbuhan Cymbopogon nardus L Sebagai Agen Antibakteri.

W, F. K. (2017). Menggunakan Metode Microwave Hydrodiffusion and Gravity. 2(1), 82-88. 